INTIQAD: JURNAL AGAMA DAN PENDIDIKAN ISLAM

ISSN 1979-9950 (print) || ISSN 2598-0033 (online), http://jurnal.umsu.ac.id/index.php/intiqad

DOI: https://doi.org/10.30596/intiqad.v11i1.3141

Vol. 11, No. 1 (Juni 2019)

\title{
Problematika Implementasi Scientific Approach dalam Pembelajaran Fikih (Studi Kasus Di MTs. PAI Medan)
}

\author{
Rahmat Rifai Lubis ${ }^{1 *}$, Haidir ${ }^{2}$, Bobi Erno Rusadi ${ }^{3}$ \\ STAI Sumatera Medan*1 \\ UMN Al-Washliyah Medan ${ }^{2}$ \\ UIN Syarif Hidayatullah ${ }^{3}$ \\ *1email: pailubis8@gmail.com \\ 2 email: haidirlubis83@gmail.com \\ 3 email: bobierno@uinjkt.ac.id
}

\begin{tabular}{l} 
Abstract \\
\hline The implementation of the 2013 curriculum hopes that \\
learning will be carried out actively. One effort to activate \\
student learning is by using a scientific approach. \\
Conceptually, this scientific approach is expected to be \\
effective in creating active and scientific students. But the \\
concept is not in line with the phenomenon of learning \\
practices in the field. Many of the students actually become \\
stiff and have difficulty in following the learning path. This \\
paper aims to find out: (1) Implementation of the scientific \\
approach in Fikih learning in MTS. PAI Medan, (2) \\
Problems in implementing the scientific approach to Fikih \\
lessons in MTS. PAI Medan, (3) Solutions to the problems \\
of the Scientific Approach in Fikih learning in MTS. PAI \\
Medan. The method used in this study is qualitative research \\
with a case study approach. The results showed that the \\
implementation of the scientific approach was carried out \\
through five teaching experiences namely observing, asking, \\
gathering information, associating, and communicating. \\
Problems in implementing the scientific approach First, the \\
unfamiliarity of students in thinking scientifically. Second, \\
student difficulties in reasoning information. Third, lack of \\
learning facilities. Fourth, the lack of learning resources \\
available in the library. Fifth, students lack courage. Sixth, \\
the function of the teacher as a facilitator sometimes does \\
not work. Seventh, students have difficulty communicating \\
the results of their scientific activities. Eighth, the \\
occurrence of knowledge gaps between students. The \\
solution to overcome these problems is to provide additional \\
knowledge through training, and form teacher working \\
groups. \\
Keywords: Implementation, Scientific Approach, Fikih \\
Learning
\end{tabular}

Artikel Info

Received:

27 Januari 2019

Revised:

18 Maret 2019

Accepted:

24 April 2019

Published:

18 Juni 2019 
Vol. 11, No. 1 (Juni 2019)

\section{Abstrak}

Implementasi kurikulum 2013 mengharapkan agar pembelajaran dilaksanakan secara aktif. Salah satu upaya mengaktifkan pembelajaran siswa yaitu dengan menggunakan pendekatan saintifik. Secara konseptual, pendekatan saintifik ini diharapkan ampuh untuk menciptakan peserta didik yang aktif dan memiliki sikap ilmiah. Namun konsep tersebut tidaklah sejalan fenomena praktik pembelajaran di lapangan. Banyak di antara siswa yang justru menjadi kaku dan kesulitan dalam mengikuti alur pembelajaran. Sehingga bukan keaktifan yang didapat namun kevakuman kelas yang hampir tak dapat terhindari. Tulisan ini bertujuan untuk untuk mengetahui: (1) Implementasi pendekatan saintifik dalam pembelajaran Fikih di MTS. PAI Medan, (2) Problematika implementasi pendekatan saintifik pada pelajaran fikih di MTS. PAI Medan, (3) Solusi atas problematika pendekatan saintifik dalam pembelajaran Fikih di MTS. PAI Medan. Metode yang digunakan dalam penelitian ini ialah penelitian kualitatif dengan pendekatan studi kasus. Hasil penelitian menunjukkan bahwa implementasi pendekatan saintifik dilaksanakan melalui lima pengalaman mengajar yakni mengamati, menanya, mengumpulkan informasi, mengasosiasi, dan mengkomunikasikan. Problematika implementasi pendekatan saintifik Pertama, ketidak terbiasaan siswa dalam berpikir secara ilmiah. Kedua, kesulitan siswa dalam menalar informasi. Ketiga, kurangnya fasilitas pembelajaran. Keempat, kurangnya sumber belajar yang tersedia di perpustakaan. Kelima, kurangnya keberanian siswa. Keenam, fungsi guru sebagai fasilitator terkadang tidak berjalan. Ketujuh, kesulitan siswa untuk mengkomunikasikan hasil kegiatan ilmiahnya. Kedelapan, terjadinya kesenjangan pengetahuan antar siswa. Adapun solusi untuk mengatasi problematika tersebut ialah memberikan pengetahuan tambahan melalui pelatihan, dan membetuk kelompok kerja guru.

Kata Kunci : Implementasi, Pendekatan Saintifik, Pembelajaran Fikih

A. Pendahuluan

Kehadiran Kurikulum 2013 memang memberikan nuansa baru dalam proses pembelajaran. Pembelajaran yang selama ini cenderung bernuansa pasif, kini berubah menjadi aktif (active learning). Perubahan nuansa ini salah satunya dipengaruhi oleh pendekatan 
pembelajaran yang bernama pendekatan saintifik (scientific approach). Pendekatan ini menekankan pada aktivitas kemandirian siswa dalam proses penemuan, pengolahan informasi, bahkan mengkomunikasikan informasi itu kembali. Dalam hal tersebut siswa tidak lagi disebut sebagai 'penerima dan pendengar budiman'. ${ }^{1}$

Pendekatan saintifik telah menjadi karakteristik utama dari proses pembelajaran berbasis kurikulum 2013. Bahkan walaupun kurikulum ini telah direvisi dengan memberikan ruang yang seluas-luasnya bagi guru untuk berkreasi dan mengembangkan proses pembelajarannya, namun tetap saja pendekatan saintifik (scientific approach) tidak dapat dilepaskan begitu saja dan diganti dengan pendekatan lainnya, sebab revisi kurikulum tersebut tetap menghendaki agar peserta didik

\footnotetext{
1 Lihat penjelasan lebih lanjut dalam Kusaeri dan Rangga Sa'adillah, Telaah Epistemologis Pendekatan Saintifik Mata Pelajaran Pendidikan Agama Islam, Islamika: Jural Studi Keislaman, Vol. 9, Nomor 2, Maret 2015, h. 1-2.
}

terbiasa untuk berpikir ilmiah. ${ }^{2}$ Untuk dapat berpikir secara ilmiah, pendekatan saintifik merupakan salah satu caranya. Maka tak salah jika sebagian tokoh mengatakan bahwa tidak sah pembelajaran disebut berbasis K-13 jika tidak menggunakan pendekatan saintifik.

Secara konseptual memang pendekatan ini diharapkan ampuh untuk menciptakan peserta didik yang aktif dan memiliki sikap ilmiah. Selain itu secara konseptual juga para guru hanya menjadi fasilitator saja untuk mengarahkan peserta didiknya agar mandiri dalam menemukan informasi baru. ${ }^{3}$ Namun konsep tersebut tidaklah sejalan fenomena praktik pembelajaran di lapangan. Banyak di antara siswa yang justru menjadi kaku dan kesulitan dalam mengikuti alur pembelajaran. Sehingga bukan keaktifan yang didapat namun kevakuman kelas yang hampir tak dapat terhindari. Para guru pun merasa terbatasi ruang gerak dan kreativitasnya

2 Eka Nugrahini (Pimpinan Redaksi), Perbaikan Kurikulum 2013, Pemberian Ruang Kreatif Pada Guru, (Majalah: Jendela: Pendidikan dan kebudayaan, Vol. III/Juni-2016), h. 12-13.

3 Marwiyah, dkk., Perencanaan Pembelajaran Kontemporer Berbasis Penerapan Kurikulum 2013, (Yogyakarta: Deepublish, 2018), h. 13-14. 
INTIQAD: JURNAL AGAMA DAN PENDIDIKAN ISLAM

ISSN 1979-9950 (print) || ISSN 2598-0033 (online), http://jurnal.umsu.ac.id/index.php/intiqad

DOI: https://doi.org/10.30596/intiqad.v11i1.3141

Vol. 11, No. 1 (Juni 2019)

karena menganggap pendekatan tersebut hanya sebagai langkah-langkah prosedural semata.

Hal ini lah yang terjadi di MTS. Pendidikan Agama Islam (PAI), berdasarkan observasi awal yang dilakukan di sekolah tersebut, tampak bahwa para guru khususnya pada pelajaran fikih kesulitan dalam menciptakan suasana pembelajaran yang aktif dan bernuansa ilmiah. ${ }^{4}$ Proses pembelajaran dengan pendekatan ini hanya dinikmati oleh para sebagian peserta didik saja, sebagian justru kerap canggung dan bingung sebab tak mampu berbaur dengan teman lainnya saat jalannya diskusi. Beberapa problematika ini sebenarnya tidak hanya terjadi pada mata pelajaran ini saja, melainkan termasuk pada pelajaran lain, namun pada artikel ini fokus kajian hanya pada pelajaran fikih saja.

Selanjutnya artikel ini secara fokus akan membahas tentang

${ }^{4}$ Bernuansa ilmiah berarti pembelajaran yang proses pembelajarannya menggunakan langkah-lagkah dan kriteria keilmiahan, yang terangkum dalam kegiatan Mengamati, Menanya, Mengeksplorasi, mengasosiasi, dan mengkomunikasikan. M. Fadlillah, Implementasi Kurikulum 2013 dalam Pembelajaran SD/MI, SMP/MTs \& SMA/MA, (Yogyakarta: Ar-Ruzz Media, 2014), h.20. implementasi pendekatan saintifik (scientific approach) di MTS. PAI Medan, problematika-problematika yang dihadapi dalam mengimplementasikan pendekatan saintifik tersebut, dan solusi untuk mengatasi problematika tersebut.

\section{B. Tujuan Penelitian}

Secara umum tujuan dari penelitian ini ialah untuk mengetahui pelbagai problematika-problematika yang dihadapi oleh guru dan siswa MTS. PAI saat pengimplementasian scientific approach dalam pelajaran fikih. Namun secara spesifik tujuan penelitian ini dapat dijabarkan menjadi beberapa poin, yakni:

1. Untuk mengetahui implementasi pendekatan saintifik dalam pembelajaran Fikih di MTS. Pendidikan Agama Islam (PAI)

2. Untuk mengetahui Problematikaproblematika dalam mengimplementasikan pendekatan saintifik pada pelajaran fikih di MTS. Pendidikan Agama Islam (PAI)

3. Untuk mengetahui solusi atas problematika pendekatan saintifik dalam pembelajaran Fikih di MTS. Pendidikan Agama Islam (PAI) 


\section{Metode Penelitian}

\section{Lokasi dan Subjek Penelitian}

Penelitian ini dilaksanakan di MTs. Pendidikan Agama Islam (PAI) yang beralamat di Jl. Pendidikan Gg. Tertib No. 8, Kelurahan Glugur Darat II, Kecamatan Medan Timur, Kota Medan. Alasan untuk memilih lokasi penelitian ini dikarenakan madrasah tersebut telah menerapkan kurikulum 2013 pada proses pembelajarannya, selain itu dikarenakan terdapat indikasi problematika yang dihadapi oleh para guru dan siswa saat pembelajaran menggunakan pendekatan saintifik.

Adapun yang menjadi subjek penelitiannya ialah para guru-guru Fikih dan siswa kelas VII dan VIII di MTS. Pendidikan Agama Islam (PAI) yang kesehariannya memang mengajar dan belajar menggunakan kurikulum 2013 dan dalam proses pembelajarannya mengunakan pendekatan saintifik.

\section{Jenis dan pendekatan Penelitian}

Metode penelitian yang digunakan ialah penelitian kualitatif, maksudnya kegiatan penelitian yang secara naturalistik mencari dan menemukan pengertian, konsep, atau pemahaman tentang fenomena dalam suatu latar yang berkonteks khusus. Secara sederhana penelitian ini akan berusaha untuk menggambarkan dan melukiskan keadaan objek penelitian pada saat sekarang sebagaimana adanya berdasarkan fakta-fakta di lapangan. Adapun pendekatan yang digunakan ialah pendekatan studi kasus, yang merupakan usaha untuk menguraikan dan menjelaskan secara komprehensif tentang fakta dan dimensi dari kasus baik dari aspek seorang individu, kelompok, organisasi (komunitas), program, maupun suatu situasi sosial. Dengan menggunakan penelitian ini peneliti akan dapat memperoleh pemahaman yang utuh dan terintegrasi mengenai interelasi berbagai fakta dan dimensi dari kasus tersebut. ${ }^{5}$

Kasus yang dimaksud di sini tentu problematika yang secara khusus terjadi di MTS Pendidikan agama Islam terkait dengan pelaksanaan pembelajaran berbasis pendekatan saintifik. Disebut khusus karena mungkin belum tentu dialami hal yang sama oleh sekolah atau madrasah lainnya.

${ }^{5}$ Lexy J. Moleong, Metodologi Peneltian Kualitatif, (Bandung: Remaja Rosdakarya, 2008), h.6. 


\section{INTIQAD: JURNAL AGAMA DAN PENDIDIKAN ISLAM}

ISSN 1979-9950 (print) || ISSN 2598-0033 (online), http://jurnal.umsu.ac.id/index.php/intiqad DOI: https://doi.org/10.30596/intiqad.v11i1.3141

Vol. 11, No. 1 (Juni 2019)

\section{Metode Pengumpulan dan} Analisis Data

Penelitian ini menggunakan metode observasi, wawancara, dan dokumentasi dalam proses pengumpulan datanya. Observasi dilakukan untuk mengamati secara lansung tentang implementasi scientific approach yang terlaksana di MTS. PAI Medan, sedangkan wawancara dilakukan untuk mengetahui apa saja problematika yang dihadapi, dan dokumentasi betujuan untuk melihat rekam kegiatan pembelajaran berbasis K-13 yang selama ini telah dilaksanakan di madrasah tersebut.

Analisis data dalam penelitian ini meliputi beberapa tahapan yakni reduksi data, penyajian data, dan penarikan kesimpulan. Lebih jelas dapat di lihat pada gambar di bawah ini:

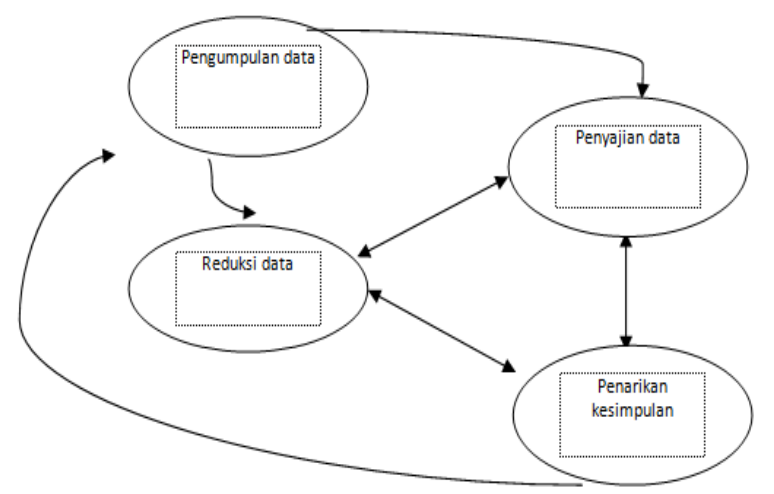

Gambar: Proses Analisa Data Kualitatif ${ }^{6}$

6 Sugiyono, Metode Penelitian Kuantitatif, Kualitatif, dan $R \& D$, (Bandung: Alfabeta, 2008), h. 246-249.
D. Pendekatan Saintifik (Scientific Approach)

Pendekatan saintifik merupakan pendekatan yang baru diperkenalkan dalam dunia pendidikan Indonesia bersamaan kehadirannya dengan kehadiran kurikulum 2013. Itu sebabnya di atas telah disinggung bahwa pendekatan saintifik merupakan karakteristik utama dari proses pembelajaran berbasis K-13.

Pendekatan saintifik juga disebut pendekatan berbasis proses keilmuan, kadang kala juga disebut dengan pedekatan berbasis keilmiahan. Pendekatan pembelajaran ini mengedepankan lima pengalaman belajar yakni mengamati, mengamati, menanya, mengeksplorasi (mengumpulkan informasi), mengasosiasi, dan mengkomunikasikan. ${ }^{7}$

Mengamati merupakan proses awal yang dilakukan dalam kegiatan inti pembelajaran. Proses ini menjadi titik awal untuk secara mandiri masuk kedalam sesuatu hal yang akan dipelajari. Proses mengamati merubah

7 Lihat lebih lanjut dalam Lampiran Peraturan Menteri Pendidikan dan Kebudayaan RI Nomor 103 Tahun 2014 Tentang Pembelajaran Pada Pendidikan Dasar dan Pendidikan Menengah. 
Vol. 11, No. 1 (Juni 2019)

paradigma dari yang selama ini siswa dianggap sebagai gelas kosong atau sama sekali tidak memiliki pengetahuan apapun. Sehingga guru yang bertugas untuk menuangkan air ke dalam gelas yang kosong tersebut. Proses mengamati oleh siswa di awal pembelajaran menunjukkan bahwa pembelajaran bertitik mulai dari apa yang telah dimiliki oleh siswa. Pengetahuan yang masih sedikit tersebut pun lantas menimbulkan rasa tanya pada diri siswa terhadap sesuatu yang telah mereka amati sebelumnya. ${ }^{8}$ Dalam hal ini saintifik juga mengubah paradigma dari yang sebelumnya guru selalu aktif bertanya untuk mengetahui dimana letak ketidaktahuan siswa, namun kini siswa secara sadar, pro dan aktif untuk bertanya atas ketidaktahuannya. Maka untuk menjawab pertanyaan guru menjadi fasilitator bagi para peserta didik untuk membantu mereka secara mandiri mengeksplorasi ataupun mengumpulkan infomasi terkait dengan pertanyaan (masalah) yang muncul tersebut. Dengan begini siswa mengerti

8 Lalu Muhammad Nurul Wathoni, Pendekatan Filsafat Pendidikan Islam; Analisis Pemikiran Filosofis Kurikulum 2013, (Ponorogo: Uwais Inspirasi Indonesia, 2018), h. 15-16. bahwa pencarian solusi terhadap pertanyaan yang dilakukannya dapat terselesaikan melalui penggalian informasi. Proses ini persis seperti proses kegiatan penelitian, namun tentu saja pada pendekatan saintifik tidak dapat dikatakan sebagai penelitian sungguhan. Setelah informasi terkumpulkan maka akhirnya peserta didik dibantu oleh pendidik untuk menalar informasi itu semua dan menghubungkan kembali antara informasi lama yang telah mereka miliki sebelumnya dengan informasi baru yang mereka dapatkan. Dengan begini secara konseptual siswa diharapkan dapat membangun sendiri kerangka berpikirnya.

Untuk mendapatkan pemahaman mendalam tentang pendekatan saintifik di bawah ini akan diuraikan beberapa yang menjadi ciri khasnya, yaitu:

1. Materi pembelajaran berlandaskan terhadap sesuatu fakta dan fenomena aktual yang dapat diamati secara logis. Dalam hal ini bukan berarti sesuatu yang bersifat fiktif tidak dapat menjadi materi pembelajaran. Sesuatu yang fiktif tidaklah menjadi materi utama tetapi menjadi materi pendukung. 
Vol. 11, No. 1 (Juni 2019)

2. Pendidik dan peserta didik terbingkai dalam kegiatan ilmiah yang interaktif. Dalam hal ini guru tidak menjadi sosok sumber segala sumber, namun menjadi sosok fasilitator dan pembimbing untuk dapat membantu siswa dalam lima pengalaman belajar tersebut.

3. Siswa menjadi sosok yang aktif, kritis, dan analitis dalam setiap proses pembelajaran berlangsung.

4. Tujuan pembelajaran disajikan secara sederhana, namun kompleks dan sistematika terarah fokus pada ketuntasan pemahaman.

5. Proses pembelajaran tidak hanya menekankan pada aspek kognitif, melainkan integrasi antara ketiga ranah yakni kognitif, afektif, dan psikomotorik

6. Mengembangkan pola berpikir yang empiris, rasional dan objektif. ${ }^{9}$

Pendekatan ini sebenarnya tidaklah jauh berbeda dengan proses atau alur penelitian ilmiah pada umumnya. Ini menunjukkan tentang kebutuhan bangsa Indonesia akan SDM yang tidak hanya

9 Ali Mudofir, Konsep Pendekatan Scientific, makalah disampaikan pada Seminar Nasional yang diadakan oleh LPTK FTK UIN Ar-Raniry di Banda Aceh, 4 September 2013, hal. 1. sekedar mengerti, namun mampu untuk mengembangkan materi pelajaran bahkan terbiasa sejak kecil untuk melakukan proses penemuan-penemuan baru. Dan ini lah sebenarnya juga yang menjadi tantangan bagi bangsa Indonesia kedepannya untuk dapat turut serta berkancah di dunia internasional.

Pendekatan saintifik pada pembelajaran kurikulum 2013 pada dasarnya memiliki prinsip, yakni memfasilitasi peserta didik akan rasa keingintahuannya, peserta didik tidak hanya menerima informasi dari pendidik saja melainkan dari berbagai sumber belajar dan informasi, pembelajaran berbasis kompetensi, proses pembelajaran yang menyeimbangkan hard-skills dan soft-skills, proses pembelajaran tempat siswa bebas berkreasi dan mengungkapkan pikiran dan idenya, dan juga tempat yang menyenangkan dan bukan sesuatu yang menjadi beban. ${ }^{10}$

\section{E. Pembelajaran Fikih}

Pada dasarnya pembelajaran itu bukanlah proses interaksi dua arah (guru

10 Lampiran Peraturan Menteri Pendidikan dan Kebudayaan RI Nomor 103 Tahun 2014 Tentang Pembelajaran Pada Pendidikan Dasar dan Pendidikan Menengah. 
dan siswa) tetapi multi arah (guru, siswa dan sumber belajar). Interaksi multi arah ini terjadi dalam lingkungan yang memungkinkan siswa untuk belajar. ${ }^{11}$ Lingkungannya dapat berupa formal (sekolah), nonformal, dan informal (masyarakat). Intinya pembelajaran merupakan proses interaksi. Proses interaksi ini dapat berupa menggali informasi, memberikan informasi, atau juga saling bertukar informasi. Sedangkan informasi itu sendiri dapat dimaknai dengan materi pembelajaran. Maka dapatlah disimpulkan bahwa pembelajaran memiliki beberapa unsur yakni subjek (guru dan siswa), proses interaksi (menemukan, menelaah, dan memecahkan, menyimpulkan), objek (informasi atau materi pelajaran), tempat (lingkungan belajar).

Fikih merupakan salah satu nama mata pelajaran yang diajarkan di madrasah. Berbeda dengan di sekolah, Fikih bukanlah nama mata pelajaran namun materi pelajaran yang include dalam rumpun mata pelajaran Pendidikan Agama Islam dan Budi Pekerti. Fikih merupakan pembelajaran yang kontennya bermuatan syariat Islam

11 Lihat lebih lanjut dalam UU No. 20 Tahun 2003 tentang Sistem Pendidikan Nasional di dalamnya tercakup ibadah, muamalah, dan siyasah. Tujuan pembelajaran ini secara umum untuk memberikan pengetahuan, sikap dan keterampilan kepada siswa tentang praktik syariat Islam dalam kehidupan sehari-hari yang terwujud dalam bentuk ibadah kepada Allah berupa shalat, puasa. Humrah, dan haji. Selain itu juga terwujud dalam bentuk bermuamalah seperti jual beli, pinjam meminjam, hutang piutang, gadai dan lainnya. Dengan memiliki pengetahuan ini diharapkan semua siswa menjadi muslim yang mampu menjalankan fungsinya sebagai seoarang manusia yakni beribadah kepada Allah Swt.

Khusus untuk tingkat MTS sktruktur kurikulum mengamanahkan dua (2) jam pelajaran tiap minggunya untuk pelajaran Fikih. $^{12}$ Jumlah ini memang terbilang sedikit, namun penyelenggara pendidikan pada dasarnya dapat menambah jam pelajaran tersebut di luar struktur kurikulum utama jika memang dibutuhkan. Karena menurut pemerintah jumlah alokasi waktu jam

12 Lihat lebih lanjut dalam Lampiran Keputusan Menteri Agama RI No 165 Tahun 2014 tentang Kurikulum 2013 Mata Pelajaran Pendidikan Agama Islam dan Bahasa Arab Pada Madrasah, h. 12. 
pembelajaran setiap kelas merupakan jumlah minimal yang dapat ditambah sesuai dengan kebutuhan peserta $\operatorname{didik}^{13}$

Pembelajaran Fikih pada K-13 dilaksanakan melalui kegiatan pembelajaran yang berciri khas keilmiahan atau dengan kata lain menggunakan lima pengalaman belajar sebagaimana yang telah disinggung pada pembahasan sebelumnya. Pembelajaran fikih tidak hanya menekankan pada aspek kognitif saja, tetapi sangat diwarnai dengan aspek keterampilan. Aspek keterampilan ini hadir dalam bentuk praktik gerakan-gerakan ibadah.

Pembelajaran pendidikan agama Islam dalam hal ini fikih cenderung dianggap sebagai pelajaran yang sifatnya menghafal bacaan-bacaan dan dalil-dalil. Adanya pendekatan saintifik siswa tidak hanya diajak cenderung dalam kegiatan seperti itu saja tetapi lebih dari itu, yakni memahami fakta dan fenoma yang terkait dengan praktik ibadah dan menghubungkannya dengan pembentukan perilaku dan sikap siswa dalam sehari-hari.

\footnotetext{
${ }^{13}$ Ibid, h. 13.
}

\section{F. Hasil Penelitian dan Pembahasan}

\section{Implementasi Pendekatan} Saintifik (scientific approach) pada Pelajaran Fikih di MTS. PAI Medan

Pendekatan saintifik mulai digunakan oleh guru-guru di MTS Pendidikan Agama Islam sejak tahun 2016, hal ini sejalan dengan penerapan Kurikulum 2013 di MTS Pendidikan Agama Islam yang sebelumnya masih menggunakan KTSP. Tahun 2016 memang terbilang terlambat jika dibandingkan dengan tahun mula diberlakukannya kurikulum tersebut pada tahun 2013. Keterlambatan ini memang dikarenakan pemerintah tidak serentak dalam memberlakukan K-13. ${ }^{14}$

Sejak tahun awal tahun 2015 para guru di MTS Pendidikan Agama Islam sudah aktif mengikuti berbagai bimbingan teknis (Bimtek) tentang penyelenggaraan pendidikan berbasis $\mathrm{K}$ 13, termasuk di dalamnya bimbingan tentang penerapan pendekatan saintifik dalam pembelajaran. Hasil wawancara penulis dengan guru pelajaran fikih bahwa mereka mulai menerapkan

\footnotetext{
${ }^{14}$ Sesuai Peraturan Pemerintah (PP) No. 32 Tahun 2013, Kurikulum 2013 diterapkan secara bertahap selama 7 tahun sejak aturan itu disahkan.
} 
Vol. 11, No. 1 (Juni 2019)

pembelajaran pendekatan saintifik sejak tahun 2016 sampai dengan saat ini.

Di MTS Pendidikan Agama Islam, aktivitas mengajar guru terdiri dari merencanakan pembelajaran, melaksanakan pembelajaran, dan mengevaluasi pembelajaran. Dalam merencanakan pembelajaran para guru (fikih) terbiasa menggunakan silabus yang telah disediakan oleh pemerintah yang mereka peroleh dari rayon utama. Dalam hal ini para guru tinggal mengembangkannya dalam bentuk Rencana Pelaksanaan Pembelajaran (RPP).

Berdasarkan hasil pengamatan yang penulis terhadap RPP guru-guru fikih di MTS pendidikan, tampak bahwa pendekatan saintifik tertulis pada bagian kegiatan inti pembelajaran. Selain itu secara tertulis juga tertera bahwa proses pelaksanaan pendekatan saintifik ini meliputi lima pengalaman belajar yakni, mengamati, menanya, eksplorasi, asosiasi, dan mengkomunikasikan. Masing-masing pengalaman belajar tersebut dijabarkan aktivitasnya dalam RPP. Contohnya seperti kutipan pendekatan saintifik dari RPP salah satu guru fikih di MTS Pendidikan Agama Islam:
- Mengamati

Secara bersama-sama siswa mengamati artikel koran tentang kerusuhan yang timbul pada saat pendistribusian zakat mal

\section{- Menanya}

Siswa diminta untuk membuat beberapa pertanyaan dari artikel yang telah mereka baca tadi, dan menuliskannya pada lembar kerja siswa yang telah di bagikan. Setelah pertanyaan terkumpul guru lantas merangkum seluruh pertanyaan siswa tadi kepada menjadi beberapa pertanyaan saja.

- Mengeksplorasi

Siswa diajak untuk keperpustakaan mencari bahan terhadap beberapa pertanyaan yang telah dirumuskan oleh guru. Pencarian dapat dilakukan melalui bahan pustaka tertulis maupun bahan pustaka yang bersumber dari internet.

\section{- Asosiasi}

Bersama dengan guru siswa di ajak untuk mendiskusikan bahan yang telah di temukan tersebut, dan siswa di minta untuk menjawab semua pertanyaan tersebut dan membantunya untuk menselaraskan pengetahuan yang mereka dapatkan dengan pengetahuan sebelumnya

- Mengkomunikasikan

Menunjuk beberapa siswa untuk mempresentasikan hasil pekerjaanya di depan kelas, di peserta didik yang lain di minta 
INTIQAD: JURNAL AGAMA DAN PENDIDIKAN ISLAM

ISSN 1979-9950 (print) || ISSN 2598-0033 (online), http://jurnal.umsu.ac.id/index.php/intiqad DOI: https://doi.org/10.30596/intiqad.v11i1.3141

Vol. 11, No. 1 (Juni 2019)

untuk memberikan komentar dan tanggapan terhadap apa yang telah disampaikan. ${ }^{15}$

Jika diperhatikan RPP guru fikih yang lain, hampir tidak ada perbedaan dalam penjabaran mengenai lima langkah pengalaman belajar. Namun berdasarkan observasi penulis terhadap aktivitas mengajarnya, terdapat sedikit perbedaan antara apa yang tertulis di RPP dengan pelaksanaan yang sebenarnya. Seperti misalnya pada kegiatan 'menanya', pada RPP tertulis bahwa guru akan merangkum seluruh pertanyaan menjadi beberapa pertanyaan saja, namun dalam praktiknya pertanyaan siswa tersebut tidak dirangkum sehingga terkadang antara satu siswa dengan lainnya memiliki pertanyaan yang sama. Dalam mengkomunikasikan misalnya siswa tidak dalam rangka untuk mempresentasikan, tetapi membawa lembar kerja yang tertulis jawaban.

Di MTS Pendidikan Agama Islam pendekatan saintifik lazim dipergunakan hampir di seluruh mata pelajaran. Hal ini sebenarnya merupakan bentuk

15 Disalin dari Rencana Pelaksanaan Pembelajaran (RPP) Mata pelajaran Fikih atas nama guru Ismail Batubara, M.Pd.I implementasi terhadap amanah yang tertuang dalam Peraturan Menteri Pendidikan dan Kebudayaan Nomor 22 Tahun 2016, tentang Standar Proses Pendidikan Dasar dan Menengah. Selain itu penerapan pendekatan saintifik juga diharapkan mampu untuk menjawab tantangan yang dihadapi para peserta didik, dan keinginan para guru untuk mendidik siswa menjadi sosok yang aktif, kritis, dan cerdas, dan terampil.

\section{Problematika Implementasi}

Pendekatan Saintifik (scientific approach) dalam Pembelajaran Fikih di MTS. Pendidikan Agama Islam

Terdapat dua problematika yang dihadapi oleh guru fikih dalam mengimplementasikan pendekatan saintifik, yakni pada saat merancang pembelajaran dan pada saat pelaksanaan pembelajaran.

- Problematika dalam hal

\section{Rancangan Pembelajaran}

Para guru kerap kali mengalami kesulitan dalam merancang indikator pembelajaran yang sesuai dengan kompetensi dasar. Hal ini terbukti dari ketidaksesuaian antara indikator dengan tujuan yang diharapkan. Selain itu pengamatan peneliti juga menunjukkan bahwa dalam merancang pembelajaran 
para guru tidak selalu mengidentifikasi karakteristik dan perilaku awal peserta didik. Sehingga kerap kali pada saat pembelajaran merasa jenuh sebab materi yang diajarkan sudah pernah dikuasai pada materi sebelumnya.

Terkait dengan menyusun langkah-langkah pembelajaran berbasis pendekatan saintifik, para guru rata-rata hanya menuliskan secara singkat saja. Hal ini disebabkan kurangnya kemampuan guru dalam menuangkan berbagai kegiatannya dalam bentuk narasi kalimat. Padahal itu merupakan sesuatu yang penting sebagai bahan untuk evaluasi setelah pembelajaran usai. Jika diperhatikan di RPP hanya tertuang lima langkah pembelajarannya saja yakni mengamati, menanya, mengeksplorasi, asosiasi, mengkomunikasikan, tanpa ada keterangan atau jika pun ada keterangan hanya sedikit. Seharusnya RPP yang baik menjelaskan aktivitas yang dilakukan oleh guru dan siswa pada setiap langkah pembelajaran tersebut. Dengan demikian tidak akan terjadi perbedaan yang signifikan antara apa yang tertulis di RPP dengan yang sebenarnya dilaksanakan.
Guru MTS PAI juga mengeluhkan tentang sulitnya membuat penilaian siswa di RPP terkait dengan aktivitas siswa selama mengikuti pembelajaran dengan alur pendekatan saintifik. Keluhan ini muncul akibat tuntutan dari jenis penilaian autentik yang menjadi ciri khas penilaian kurikulum 2013. Guru fikih di MTS pendidikan Agama Islam cenderung untuk menilai hasil belajar saja dalam bentuk kognitif. Padahal dalam K-13 penilaian dilakukan juga selama aktivitas pembelajaran berlangsung. Dengan demikian para guru kerap kali hanya melaksanakan pembelajaran tanpa memberikan catatan tertulis terhadap kinerja dan hasil belajar siswa. Tentu saja hal ini semua bermuara dari kesulitan guru dalam mrancang penilaian pembelajaran berbasis penilaian autentik.

\section{- Problematika dalam pelaksanaan pembelajaran}

Tentu sangat banyak problem ataupun kendala yang dihadapi guru dan siswa saat menggunakan pendekatan saintifik dalam pembelajaran fikih, di antaranya: Pertama, ketidakterbiasaan siswa dalam berpikir secara ilmiah. Lima pengalaman belajar saintifik lebih di 
anggap sebagai kegiatan procedural ketimbang kegiatan natural. Sehingga hasilnya para siswa kerap mendapatkan pengetahuan yang parsial ketimbang holistik. Kedua, kesulitan siswa dalam menalar informasi yang diberikan pada saat proses pengamatan berlangsung. Pengalaman belajar awal yang dilakukan peserta didik ialah mengamati, tujuannya ialah untuk menggali pengetahuan awal yang telah dimiliki oleh peserta didik, sehingga menjadi modal awal untuk masuk pada materi berikutnya. Namun kerap kali para siswa tidak mengamati, melainkan hanya sekedar membaca. Ketiga, kurangnya fasilitas pembelajaran seperti audiovisual yang sudah tentu sangat dibutuhkan terutama dalam proses pengamatan, mengasosiasi, dan presentasi. Keempat, kurangnya sumber belajar yang tersedia di perpustakaan. Pembelajaran fikih tentu membutuhkan referensi yang banyak terutama dalam memahami berbagai macam ketentuan para ulama tentang syariat Islam, dalam hal ini MTS Pendidikan Agama Islam hanya memiliki 135 referensi keagamaan, dari dari 135 hanya sekitar $30 \%$ nya saja yang berkaitan dengan fikih. Kelima, kurangnya keberanian siswa dalam mengutarakan pertanyaan, pendapat, ataupun saran dan masukan baik dalam kegiatan individual maupun dalam kegiatan kelompok. Keenam, fungsi guru sebagai fasilitator terkadang tidak berjalan. Dalam hal ini seharusnya siswa lebih aktif menggali, menganalisis, serta menyimpulkan informasi, namun karena ketidakmampuan siswa sehingga guru kerap ikut serta dalam kegiatan menggali, menganalisis, bahkan terkadang juga sampai menyimpulkan informasi. Ketujuh, kesulitan siswa untuk mengkomunikasikan hasil kegiatan ilmiahnya. Tidak semua siswa mampu untuk berkomunikasi di depan kelas, pada saat pembelajaran siswa lebih tertarik untuk menjadi pendengar yang budiman. Kedelapan, terjadinya kesenjangan pengetahuan antar siswa, hal ini lebih disebabkan karena ketidakmampuan guru dalam memberikan pemerataan kesempatan dalam proses pembelajaran. Seperti misalnya tidak adanya giliran dalam mempresentasikan hasil diskusi, tidak diberikan kesempatan kepada yang lain dalam mengutarakan pendapat dan sebagainya.

Semua problematika yang telah dijelaskan di atas tentu bermuara pada kurangnya keberhasilan penerapan 
pendekatan saintifik. Namun perlu untuk ditambahkan dalam peneltiian ini bahwa sebenarnya guru berhak untuk berkreasi untuk mengelola sendiri pembelajarannya, dengan kata lain tidak mesti harus dengan lima tahapan pengalaman belajar. Guru dapat saja menggantinya dengan pengalaman belajar yang lain, namun dengan catatan tetap harus bernuansa kegiatan ilmiah. Sehingga siswa tidak hanya sekadar dapat memahami materi saja, tetapi di kemudian hari terbiasa memecahkan masalah, bahkan terampil memberikan solusi.

\section{Solusi atas Problematika} Implementsi Pendekatan Saintifik di MTS. Pendidikan Agama Islam (PAI)

Pada dasarnya bukan hanya guru Fikih saja yang mengeluh dan kesulitan dalam penerapan pendekatan saintifik, tetapi hampir dirasakan oleh seluruh guru. Untuk mengatasi hal ini Madrasah mengeluarkan kebijakan untuk mengadakan workshop pelatihan implementasi pendekatan saintifik. Kegiatan ini diadakan dalam lingkungan madrasah dan diikuti oleh seluruh guru bidang studi umum dan agama. Melalui kegiatan ini diharapkan dapat memperbaiki kualitas aktivitas mengajar guru.

Tindak lanjut (follow-up) dari kegiatan workshop tersebut para guru diperintahkan untuk membuat KKG, kelompok kerja guru dalam lingkungan rayon. Dengan bergabungnya para guru dalam wadah $\mathrm{KKG}$ ini maka guru dapat saling bertukar informasi, menyampaikan keluh kesah, permasalahan, dan juga saling bertukar pengalaman mengajar. Tidak hanya itu bahkan dalam lingkup madrasah pun para guru satu rumpun mata pelajaran diminta untuk membuat kelompok kerja, sehingga problematika selama ini dapat teratasi.

Dalam workshop para guru sebenarnya dibekali juga dengan pengetahuan metode dan strategi pembelajaran selain pendekatan saintifik, tujuannya agar terdapat kombinasi pembelajaran di dalam kelas, sehingga siswa tidak menjadi cepat bosan terhadap model pembelajaran yang selalau hampir tak pernah bertukar.

\section{G. Simpulan}

Secara konsep pendekatan saintifik memang berusaha untuk menselaraskan pembelajaran dengan tuntutan zaman 
yang sarat akan kegiatan ilmiah. Selain itu secara konsep juga pendekatan saintifik dirancang untuk dapat merubah paradigma dari yang selama ini pembelajar pasif berubah menjadi pembelajar aktif. Namun pada kenyataannya tidaklah selalu sejalan dengan konsep yang telah direncanakan. Terdapat berbagai problematika yang dihadapi. Mulai dari kegiatan merancang pembelajaran, melakanakan pembelajaran, sampai mengevaluasi pembelajaran.

Namun walaupun terdapat problematika bukan berarti kita menghilangkan pendekatan ini dan tidak menggunakannya lagi, melainkan mencari titik kesalahannya untuk diperbaiki. Penguasaan dan terampil dalam mengimplementasikan pendekatan saintifik tidaklah didapat hanya dalam sekali menerapkannya, melainkan dilakukan dengan cara berulang-ulang. Begitu juga dengan siswa, jika hanya sekali saja belajar menggunakan pendekatan ini tentu menimbulkan kebingungan.

Bagaimanapun pemilihan pendekatan dan strategi pembelajaran harus disesuaikan dengan materi pelajaran, karakteristik peserta didik, bahkan tipe belajar siswa. Untuk itu pemilihan terhadap pendekatan saintifik merupakan satu pilihan yang didasarkan atas identifikasi kebutuhan yang telah dilakukan sebelumnya. Sebaik apapun konsep pendekatan yang digunakan tentu tidak akan berhasil manakala tidak sesuai dengan kondisi dan kebutuhan peserta didik.

\section{Daftar Pustaka}

Fadlillah, M. (2014). Implementasi Kurikulum 2013 dalam Pembelajaran SD/MI, SMP/MTs \& SMA/MA. Yogyakarta: Ar-Ruzz Media

Kusaeri dan Rangga Sa'adillah. (2015).

Telaah Epistemologis Pendekatan Saintifik Mata Pelajaran Pendidikan Agama Islam, Islamika: Jural Studi Keislaman, Vol. 9, No. 2.

Lampiran Keputusan Menteri Agama RI No 165 Tahun 2014 tentang Kurikulum 2013 Mata Pelajaran Pendidikan Agama Islam dan Bahasa Arab Pada Madrasah. Jakarta.

Lampiran Peraturan Menteri Pendidikan dan Kebudayaan RI Nomor 103 Tahun 2014 Tentang Pembelajaran 


\section{INTIQAD: JURNAL AGAMA DAN PENDIDIKAN ISLAM}

ISSN 1979-9950 (print) || ISSN 2598-0033 (online), http://jurnal.umsu.ac.id/index.php/intiqad DOI: https://doi.org/10.30596/intiqad.v11i1.3141

Vol. 11, No. 1 (Juni 2019)

Pada Pendidikan Dasar dan

Pendidikan Menengah. Jakarta.

Marwiyah, dkk,. (2018). Perencanaan Pembelajaran Kontemporer Berbasis Penerapan Kurikulum 2013. Yogyakarta: Deepublish

Moleong, Lexy J. (2008). Metodologi

Peneltian Kualitatif. Bandung:

Remaja Rosdakarya.

Mudofir, Ali. Konsep Pendekatan Scientific. Makalah Seminar Nasional LPTK FTK UIN ArRaniry Banda Aceh, 4 September 2013

Nugrahini, Eka. (2016). Perbaikan Kurikulum 2013, Pemberian Ruang Kreatif Pada Guru, Majalah: Jendela: Pendidikan dan kebudayaan, Vol. III/Juni.

PP RI Nomor 32 tahun 2013 tentang perubahan atas Peraturan Pemetintah Nomor 19 Tahun 2005 tentang Standar Nasional Pendidikan. 7 Mei 2013. Lembaran Negara republik indonesia tahun 2013 Nomor 71. Jakarta

Sugiyono. (2008). Metode Penelitian Kuantitatif, Kualitatif, dan $R \& D$. Bandung: Alfabeta.

UU No. 20 Tahun 2003 tentang Sistem Pendidikan Nasional, 8 Juli 2003. Lembaran Negaa Republik Indonesia tahun 2003 Nomor 4301. Jakarta

Wathoni, Lalu Muhammad Nurul. (2018). Pendekatan Filsafat Pendidikan Islam; Analisis Pemikiran Filosofis Kurikulum 2013. Ponorogo: Uwais Inspirasi Indonesia 